ПРОБЛЕМА ПРОФЕСІЙНОЇ ПІДГОТОВКИ МАЙБУТНІХ ФАРМАЦЕВТІВ ЗА УМОВ УПРОВАДЖЕННЯ ЕЛЕМЕНТІВ ДИСТАНЦІЙНОГО НАВЧАННЯ

\title{
THE PROFESSIONAL TRAINING PROBLEM OF FUTURE PHARMACISTS DURINGIMPLEMENTATION OF ELEMENTS OF DISTANCE LEARNING
}

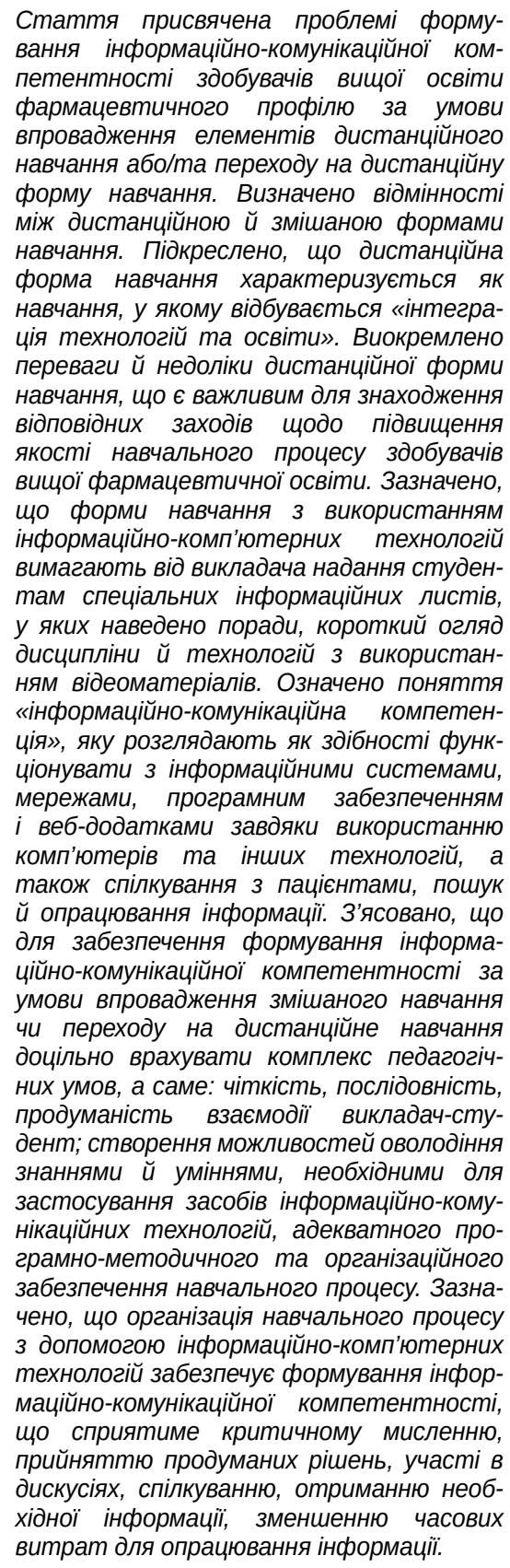

Стаття присвячена проблемі формуформацевтичного профрілю за умови впровадження елементів дистаниійного навчання або/та переходу на дистанційну форму навчання. Визначено відмінності навчання. Підкреслено, що дистанчійна форма навчання характеризується як навчання, у якому відбувається «інтегра( навчання, що є важливим для знаходження відповідних заходів щодо підвищення якості навчального процесу здобувачів вищої фрармачевтичної освіти. Зазначено, що сорми навчання 3 використанням норормаційно-комп'ютерних технологій у яких наведено поради, короткий огляд дисципліни й технологій з використанням відеоматеріалів. Означено поняття «інфрормаційно-комунікаційна компетенчія», яку розглядають як здібності фрунксистемами дяки використанню комп'ютерів та інших технологій, а с для забезпечення формування інформаційно-комунікаційної компетентності за умови впровадження змішаного навчання чи переходу на дистанційне навчання дочільно врахувати комплекс педагогіч -

УДК 378:37.018.43

DOI https://doi.org/10.32843/2663-

$6085 / 2020 / 28.29$

\section{Драчук M.I.,}

канд. пед. наук,

старший викладач кафедри біофрізики

Львівського національного медичного університету імені Данила Галицького

Федорович 3.Я.,

канд. біол. наук,

доцент кафедри біофізики

Львівського національного медичного

університету імені Данила Галицького
Ключові слова: студенти-провізори, інформаційно-комунікаційна компетентність дистанційне навчання, змішане навчання.

The article introduces the problem formation of information and communication competence of higher education of pharmaceutical profile during the process of introduction the distance learning elements and/or distance learning (e-education). It discusses the differences between distance learning and blended learning. The distance learning is characterized as learning there is an "integration of technology and education". The advantages and disadvantages of distance learning are highlighted, which is important for finding appropriate measures to improve the quality of the educational process of graduates of higher pharmaceutical education. It is noted that forms of learning with the application of the information and computer technology require the teacher to provide students with special information notes, with advice and a brief overview of the discipline and technology with the use of video materials. The concept of "information and communication competence" which is considered as the ability to function with information systems, networks, software and web applications through the use of computers and other technologies, as well as communication with patients, search and processing of information. It was found that to ensure the formation of information and communication competence in the implementation of the blended learning or the transition to the distance learning, it is advisable to take into account a set of the pedagogical conditions, namely clarity, consistency, thoughtful teacherstudent interaction; creation of opportunities for mastering the knowledge and skills necessary for the application of information and communication technologies; adequate program-methodical and organizational support of the educational process. It is noted that the organization of the educational process with the help of the information and computer technologies provides the formation of the information-communication competence, which will develop student's critical thinking skills, making informed decisions, participating in discussions, communication, obtaining the necessary information, reducing time spent on information processing.

Key words: students-pharmacists, information and communication competence, distance learning, blended learning.
Постановка проблеми в загальному вигляді. Традиційна фрорма навчання та викладання вимушено змінена в закладах освіти на дистанційне чи змішане навчання через пандемію COVID-19 i переведена на електронні платформи. Таке навчання визначається як навчання, де інорормація, завдання та виконані праці надходять через електронні пристрої, такі як мобільні пристрої, персональні комп'ютери та інші гаджети. Окрім того, навчання з використанням електронних платформ характеризується унікальними особливостями та принципами роботи, що стосуються вдосконалення інорормаційних і цифрових навичок, які водночас сповільнюють і розширюють можливості учасників навчального процесу ефективно проводити (здійснювати) навчання [1, с. 297].

Без сумніву, головною метою освіти $є$ підготовка висококваліфрікованого фрахівця, готового 
ефрективно та профресійно працювати, а також бути конкурентним на ринку праці, тому новітні технології в навчанні, що достатньо адаптовані до конкретних умов праці, повинні зробити здобувача вищої фрармацевтичної освіти носієм нових знань та ідей [2, с. 122]. Програми дисциплін, що вивчаються майбутніми фрахівцями фрармацевтичної галузі, повинні давати можливість розвивати інфрормаційно-комунікаційну компетентність, необхідну для подальшої професійної діяльності й наукових досліджень, а не лише для виконання навчального навантаження $з$ кожного окремо взятого предмета.

Зазначимо, що інфрормаційно-комунікаційну компетентність провізорів як один 3 елементів професійної компетентності досить часто варто розглядати як сукупність їхніх фрахових якостей, в основі яких лежать здібності, знання, уміння й навички в галузі освоєння нових інфрормаційних технологій, а також досвіду їх застосування в професійній діяльності [3, с. 89]. Отже, реалізується основний принцип «навчання продовж життя» та розвиток післядипломної спеціалізації.

Освітній вектор спрямовано на досвід європейських країн, який у більшості європейських країн регулюються рекомендаціями EAFP (European Association of Faculties of Pharmacy), які прийняті Директивою ЄС 85/432. Вона рекомендує п'ятирічну університетську програму навчання й шестимісячну практичну підготовку в аптечній установі. Тому справедливим $€$ залучення нових наукоємних технологій в освітній процес для досягнення європейського рівня у вітчизняній фрармацевтичній освіті. У професійній діяльності провізори зобов'язані вміти використовувати сучасне апаратне і програмне забезпечення, усвідомлено застосовувати інсрормаційні комп'ютерні технології в професійній діяльності, тобто володіти інфрормаційною компетентністю.

Отже, в умовах всезростаючої інфрорматизації вищої освіти, а також за умов дистанційного навчання або навчання з елементами дистанційного навчання інформаційно-комунікаційну компетентність потрібно починати фрормувати продовж освітнього процесу в профрільних закладах вищої освіти [4, с. 76].

Аналіз останніх досліджень і публікацій. Дослідженням розвитку й організації змішаної та дистанційної форми навчання в Україні присвячено праці таких науковців, як О. Андрєєва, Т. Білик, Л. Галій, Г. Гомелюк, М. Гребеник, Г. Дегтярова, Т. Марусей, Г. Козлакова, В. Кухаренко та інші.

Вивченням сучасних тенденцій використання інформаційних технологій під час дистанційного навчання займалися Ю. Рашкевич, І. Федорчук та інші.

Питанню орормування інфрормаційно-комунікаційної компетенції провізорів у системі вищої освіти присвячено наукові праці таких науковців, як Н. Баловсяк, В. Биков, Р. Гуревич, А. Гуржій, А. Добровольська, Н. Іваньокова, М. Кадемія, Л. Кайдалова, В. Кобися, О. Овчарук, О. Рижов та інші.

Виділення не вирішених раніше частин загальної проблеми. Питання щодо формування інфрормаційно-комунікаційної компетентності як однієї з профресійних компетентностей особливо за впровадження змішаного чи дистанційного навчання $€$ актуальним в умовах сьогодення в підготовці майбутніх провізорів.

Метою статті $€$ дослідження фрормування та розвитку інформаційно-комунікаційної компетентності в умовах ефективного поєднання очнодистанційної чи дистанційної фрорми організації навчального процесу майбутніх провізорів.

Виклад основного матеріалу. Підготовка фахівців фрармацевтичної галузі в Україні потребує постійного вдосконалення та пошуку новітніх шляхів організації навчального процесу. У карантинних умовах освітній процес переведено на дистанційне навчання, яке окреслюють як універсальну гуманістичну форму навчання, що базується на використанні широкого спектру традиційних і телекомунікаційних технологій і створює додаткові умови для студента, а саме: вільний вибір освітніх дисциплін, що відповідають міжнародним стандартам, діалоговий обмін 3 викладачем тощо [5]. Окрім того, дистанційне навчання визначають як «спосіб освіти, за якого викладач і той, кого навчають, розділені просторово» [6]. На думку О. Глушаченко, це «індивідуалізований процес набуття знань, умінь, навичок і способів пізнавальної діяльності особистості, який відбувається переважно за опосередкованої взаємодії віддалених один від іншого учасників освітнього процесу в спеціалізованому середовищі, яке функціонує на базі сучасних психолого-педагогічних та інорормаційно-комунікаційних технологій» [7, с. 14]. Отже, дистанційне навчання має різні визначення та характеризується як навчання, у якому відбувається «інтеграція технологій та освіти» [8, с. 67].

Аналіз літературних джерел указує на переваги й недоліки дистанційного навчання [9, с. 227; 10 , с. $92 ; 11$, с. $36 ; 12$, с. 143]. Вагомими перевагами дистанційного навчання $€$ таке: вибір місця навчання, опрацювання навчального матеріалу відбувається в зручний час, наприклад, лекційний курс, попередньо записаний у відеоформаті, уможливлює його перегляд у зручний для студента час, навчальний матеріал розміщений на електронній платорормі. Проте $є$ й недоліки в системі дистанційного навчання, а саме відсутність очного спілкування в системі викладач-студент, ідентифрікація студента при виконанні тестових завдань (хоча кожен студент працює під власним 
логіном і паролем), наявність технічного забезпечення та Інтернет, неможливість використання у вивченні дисциплін, що потребують обов'язкового засвоєння практичних навичок, наявність методичного забезпечення, дизайн навчального матеріалу повинен бути сумісним для різних технічних засобів (наприклад, ноутбук, смартфон тощо); уміння учасників навчального процесу працювати 3 інфрормацією, а також мотивація, підтримання самодисципліни та вміння самоорганізуватися при виконанні навчального навантаження. Отже, аналіз переваг і недоліків дистанційного навчання $€$ важливим для вжиття відповідних заходів щодо підвищення якості навчального процесу.

У сучасній педагогіці під змішаним навчанням розуміють об'єднання засобів денної форми навчання - роботи в аудиторіях, вивчення теоретичного матеріалу - 3 такими методами, що передбачають, наприклад, обговорення навчального матеріалу за допомогою електронної пошти й інтернет-конфреренцій [13, с. 238]. Так, при змішаній формі навчання лекційний матеріал $є$ в доступі студентів ще до лекційних занять, тоді як у час проведення лекційного заняття студенти можуть опрацювати разом із лектором незрозумілі моменти чи питання, які виникли після перегляду запису лекції. Аудиторно при змішаній формі навчання проводять лабораторно-практичні заняття, на яких фрормуються навички. Варто зауважити, що форми навчання з використанням інформаційних технологій вимагають від викладача надання спеціальних інформаційних матеріалів, у яких зазначені поради, короткий огляд курсу, представлений мультимедійно [14, с. 317].

Отже, змішана фрорма навчання органічно поєднує як очну, так і дистанційні форми навчання. Інфрормаційно-комунікаційні технології $€$ невід'ємною частиною сучасної практики фахівців фрармацевтичної галузі. Очевидно, що розвиток навичок застосування інформаційно-комунікаційних технологій важливий, щоб випускники були «готовими до роботи» й адекватно підготовленими до практики в дедалі більш технологічних середовищах охорони здоров'я.

Компетенції, у тому числі інформаційно-комунікаційна, які здобувають майбутні провізори, зазначені в робочих навчальних програмах. Інформаційно-комунікаційну компетенцію розглядають як здібності фрункціонувати 3 інформаційними системами, мережами, програмним забезпеченням і веб-додатками завдяки використанню комп'ютерів та інших технологій, а також спілкування з пацієнтами, пошук й опрацювання інформації [15, с. 612]. Однією з вимог фрормування інфрормаційно-комунікаційної компетентності $€$ комплекс педагогічних умов, а саме чіткість, послідовність, продуманість взаємодії викладач-студент; створення можливостей оволодіння знаннями й уміннями, необхідними для застосування засобів інформаційно-комунікаційних технологій, адекватного програмно-методичного та організаційного забезпечення навчального процесу [16, с. 192].

Проте робочі програми в основі розроблені для очної фрорми навчання. Варто зазначити, що як дистанційна, так і змішана фрорми навчання вимагають розробки навчальної програми, виконання якої забезпечує розвиток інформаційно-комунікаційної компетентності. Упровадження таких заходів у навчальний процес, а також використання інорормаційно-комунікаційних технологій сприятиме критичному мисленню, прийняттю продуманих рішень, участі в дискусіях, спілкуванню, отриманню необхідних даних, зменшенню часових витрат для опрацювання інфрормації.

Перехід до дистанційного навчання відбувся швидко, що зумовлено поширенням короновірусної інфрекції COVID-19 [17; 18]. Університет використовує електронну платорорму Moodle. Студенти можуть переглядати теоретичний матеріал, виконують завдання та здають поточний і підсумковий тестовий контроль на цій електронній платформі. Отже, важливим залишається розвиток навичок роботи з комп'ютером у нинішній «трансорормованій» освіті.

Висновки. Отже, необхідність упровадження змішаної чи дистанційної фрорм навчання вказала на потреби враховувати зміни сьогодення, які, з одного боку, зумовили проблемність їх упровадження, а 3 іншого - спонукають до переходу до інноваційної діяльності, пов'язаної з упровадженням інорормаційно-комп'ютерних технологій, і культури мислення, що відображається на формуванні інформаційно-комунікаційної компетентності фрахівців фрармацевтичної галузі. При використанні інфрормаційно-комп'ютерних технологій варто звернути увагу на розроблення змісту методичного забезпечення дисциплін та органічно використовувати у фраховій діяльності майбутніх провізорів.

\section{БІБЛІОГРАФІЧНИЙ СПИСОК:}

1. Uzule $\mathrm{K}$. Teacher training and education programs in Latvia: are e-competences included? Business, Management and Education. 2020. № 18 (2). P. 294-306.

2. Осін А.В. Мультимедіа в освіті: контекст інформатизації. 2004. 320 C.

3. Добровольська А.М. Формування і розвиток IT-компетентності майбутніх лікарів і провізорів за умови інтеграції дисциплін природничо-наукової підготовки. Збірник наукових праць Уманського державного педагогічного університету імені Павла Тичини. 2016. № 1. С. 87-100.

4. Бабінцева Л.Ю. Теоретико-методологічне обґрунтування інформаційного моніторингу фрармацевтичного ринку в системі охорони здоров'я : дис. ... докт. біол. наук : 14.03.11 «Медична та біологічна інфрорматика і кібернетика». Київ, 2015. 298 с. 
5. Актуальні питання дистанційної освіти та телемедицини. Матеріали Всеукраїнської науково-практичної відео-конференції, 16-17 квітня 2009 р. Запоріжжя : Вид-во ЗДМУ, 2009. 170 с.

6. Слєпкань 3.I. Наукові засади педагогічного процесу у вищій школі : навчальний посібник. Київ, 2005. 239 c.

7. Глушаченко О. Перспективи впровадження дистанційних методів навчання для студентів заочної форми навчання фрармацевтичного фракультету Національного медичного університету імені О.О. Богомольця. Людинознавчі студії. Серія «Педагогіка». 2015. Вип. 1. С. 12-18.

8. Al-Frahait D., Joy M., Masa'deh R., Sinclair J. Evaluating e-learning systems success:Anempirical study. Computers in Human Behavior. 2020. № 102. Pp. 67-86.

9. Власенко Л.В. Переваги та недоліки дистанційного навчання. Профресійна підготовка педагога: історичний досвід і виклики сучасності. Збірник наукових праць. Дрогобич : Редакційно-видавничий відділ Дрогобицького державного пед. університету ім. I. Франка, 2013. С. 224-228.

10. Пастушенко О.А. Переваги та недоліки дис-

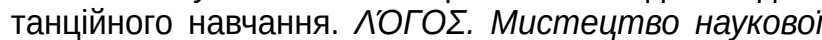
Әумки. 2019. № 4. С. 91-93.

11. Гроссу Н.В. Дистанційна освіта: переваги та недоліки. Tendenze attuali della moderna ricerca scientifica: der Sammlung wissenschaftlicher Arbeiten

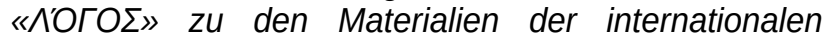
wissenschaftlich-praktischen Konferenz. 5 Juni, 2020. Stuttgart : Europäische Wissenschaftsplattform, 2020. № 2. S. 35-37.
12. Bin Mubayrik H.F. Exploring Adult Learners; Viewpoints and Motivation Regarding Distance Learning in Medical Education. Advances in medical education and practice. 2020. № 11. P. 139-146.

13. Bliuc A., Casey G., Bachfischer A. et al. Blended learning in vocational education: teachers' conceptions of blended learning and their approaches to teaching and design. 2012. № 39. P. 237-257.

14. Ilyashenko L.K., Gladkova M.N., Kutepov M.M., Vaganova O.I., Smirnova Z.V. Development of communicative competencies of students in the context of blended learning. Amazonia investiga. 2019. № 8 (18). P. 313-322.

15. Levett-Jones T., Kenny R., Van der Riet P., Hazelton M., Kable A., Bourgeois S., Luxford Y. Exploring the information and communication technology competence and confidence of nursing students and their perception of its relevance to clinical practice. Nurse Education Today. 2009. № 29 (6). P. 612-616.

16. Федяєва М.С. Організаційно-педагогічні умови формування інформаційно-комунікаційної компетентності студентів-економістів. Профресійна освіта: методологія, теорія та технології. 2016. № 3. $298 \mathrm{c}$.

17. Положення про дистанційне навчання : Наказ MOH України від 25.04.13 № 466. URL: http:// osvita. ua/legislation/Dist_osv/2999/print (дата звернення: 10.06.2020).

18. Щодо організації дистанційного навчання в закладах загальної середньої освіти під час карантину. URL: https://cutt.ly/dyB9CuF (дата звернення: 10.06.2020). 